\title{
交通行動の居住地選択行動への影響を仮定した 都市動態のマルチェージェントシミュレーション
}

\author{
谷 口忠 大*・高 橋 佑 輔**
}

\begin{abstract}
Multi-agent Simulation about Urban Dynamics Based on a Hypothetical Relationship between Individuals' Travel Behavior and Residential Choice Behavior
\end{abstract}

Tadahiro TANiguchi* and Yusuke TAKAHASHI**

\begin{abstract}
In this paper, we proposed a simple urban model including individuals' travel behavior and residential choice behavior. Multi-agent simulation framework is described. We performed several experiments to evaluate political measures which will solve problems about motorization. As a result, drastic mobility management scheme increased the number of travelers using a train, and the distribution of residences became compact. However, it also increased many agents' total costs of living because of high rent and several kinds of cost including time cost and fatigue cost to reach a station. On the other hand, raising gas price made $\mathrm{CO}_{2}$ emission less and kept total cost of living lower than the drastic mobility management measure. This suggests that to have people use train or bus by changing their attitude might be socially more expensive than to make people chose whether they use car or not under the condition that gas price is raised.
\end{abstract}

Key Words: multi-agent simulation, mobility managemanet, travel behavior

\section{1.はじめに}

私たちの都市空間は日々の経済活動の中でダイナミックに 変容する動的なパターンである。それらは日常生活の中では 固定されているように見えるが, 数年の中期で見ると徐々に 変化し，数十年以上の長期で見ると大きく姿を変えている. 特に近年は, 環境・エネルギー問題や, 地方の経済問題など が相互に関連しあいながら都市構造の問題が多方面から議論 されてきている。 その中で, モータリゼーションが私達の都 市環境を流動化させ不安定化させていると指摘されている ${ }^{1)}$. たとえば，地方都市における市街地の賑わいは郊外に開発さ れた大型ショッピングモールに顧客を奪われることで衰退し， 空洞化した都心，および自動車の往来が激しくなった郊外で は, 交通渋滞, 少年犯罪の増加, 地域コミュニティの走失と いったさまざまな負の影響を与えているといわれている ${ }^{2)}$. これらに加え，枯渇する化石資源へのエネルギー依存という 根本的な現代社会の問題を克服するために, コンパクトシティ への道が模索されている ${ }^{3)}$.コンパクトシティでは都市の機 能がその中心に集約され, 人々が電車やバスといった公共交

* 立命館大学情報理工学部 草津市野路東 1-1-1

** 北陸先端科学技術大学院大学知識科学研究科 能美市旭台 1-1

* Department of Human \& Computer Intelligence, Ritsumeikan University, 1-1-1 Nojihigashi, Kusatsu

** School of Knowledge Science, JAIST, 1-1 Asahidai, Nomi (Received February 17, 2011)

(Revised September 14, 2011)
通，および自転車や徒歩といった交通手段を主に用いて移動 することで，賑わいのあるまちづくりが目指される。

近年, 藤井らは交通行動が居住地選択に及ぼす影響につい ての調査研究を行ない, 居住地選択行動がそれ以前の交通行 動選択の影響を受けることを指摘した。これにより，コミュ ニケーション施策を中心としたソフト施策であるモビリティ マネジメントによりコンパクトシティへ都市を導くことがで きる可能性を指摘した ${ }^{4)}$. 本研究では, 藤井らの仮説を前提 としつつ，自動車利用を抑制するどのような施策が個人の交 通行動変化と居住地選択行動変化を介して, 都市構造の変化 を生み出していくのかをマルチエージェントシミュレーショ ンを用いて構成的に検証し，その構造について議論する。ま た，あまり注目されてこなかった自転車に対する施策につい て，同シミュレーションモデルを用いて検討する.

\section{2. 研 究 背 景}

2.1 コンパクトシティとモビリティマネジメント

近年，地方の都市の多くが無個性化し郊外化していると指 摘される。この一因は自動車の急速な普及にあり，このモー タリゼーションが都市を低密度に広げ，また住人の生活ス夕 イルを変容させていると考えられている ${ }^{1)}$ 。この都市の変化 はマクドナルド化やファスト風土化などと形容される ${ }^{2), 5)}$. その弊害は，ガソリン消費の増加だけでなく，警察などの公 共サービスの維持コストの増加や，住人の匿名化，コミュニ ティの衰失，中心市街地の没落など多岐にわたる。この問題 
を解決し，コンパクトシティを実現することが多くの地域， 人々，行政によって目指されている.

コンパクトシティとは都市機能を高密度に集約し, 人々が コンパクトに住まう町の形である ${ }^{3), 6)}$. その定義は, 分野, 関係者ごとにゆらぎがあり完全な了解は得られていないが, さまざまな定義の中にも，二点ほどの共通点が見られる。一 つは, 都市空間がコンパクトになっていること，もう一つは, クルマ中心でなく公共交通や歩行者を中心としたまちづくり であることである．歩行者を中心としたまちづくりはジェイ コブスなどにより古くから主張されてきたが，街路のもつコ ミュニティ機能など，多様性を内包したまちづくりは，マク 口視点の都市計画では見落とされがちであったが, 近年は重 要な事項として認識されてきている7). しかしながら, コン パクトシティをいかにして実現するかは難しい問題となって いる.

一方で，モータリゼーションからの脱却は，石油の枯渇を 背景としたエネルギー問題を鑑みても喫緊の課題であり，ま ちづくりの課題と関係させながら議論されてきている，その 中で，脱クルマを実現するための施策としてモビリティマネ ジメントが注目されている。モビリティマネジメントとは当 該の地域や都市を「過度に自動車に頼る状態」から，「公共交 通や徒歩などを含めた多様な交通手段を適度に（=かしこく） 利用する状態」へと少しずつ変えていく一連の取り組みを意 味するものである ${ }^{8)}$. モビリティマネジメントの手段として， 公共交通の整備では新型路面電車 LRT の導入が注目を集め ているし9),10), また, パークアンドライドやロードプライシ ングなどの施策も注目を集めている，一方で，近年のモビリ ティマネジメントの研究においては, トラベルフィードバッ クプログラム (TFP: Travel Feedback Program)をはじめと したコミュニケーション施策が注目されている(注 1)。これは 対象とする人々，一人一人と個別的かつ大規模にコミュニケー ションをとることを通じて一人一人の意識と行動の変容を促 すものである ${ }^{8)}$. このように道路の敷設や公共交通の整備と 行なったハード施策のみならず, コミュニケーションや情報 提供, 料金体系の改善などのソフト施策も導入することで脱 モータリゼーションを実現する研究・施策がなされている.

コンパクトシティを実現するためには土地利用や交通行動 の変容にかかわる施策を一体的に実現することが重要である といわれるが, 近年, モビリティマネジメントとコンパクトシ ティ形成の関係性が指摘されている，谷口らは，都市のコン パクト化と共に，モビリティ・マネジメント施策を協調させ ることの必要性をシナリオ分析から指摘している ${ }^{12)}$. また, 藤井らは転居前の交通行動が習慣として転居後にも引き継が れるために生じる, 居住地選択行動への影響を指摘し, 高崎 市を対象としたアンケート調査を通して検証している ${ }^{4), 13)}$. つまり, クルマに乗っている住人は転居先でもクルマに乗る

（注 1）オーストラリアのパースで大規模な TFP 施策「トラベ ルスマート」が実施され, 成果を上げた。 日本でも, 京都府や札

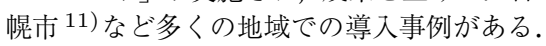

可能性が高く，ゆえに，クルマに乗ることを基準として転居 先を決定するという考え方である。これを認めると，モビリ ティマネジメントを通して, 住人のクルマ利用を控えさせる ことで, 徐々にクルマを利用しないことを前提とした転居を 誘発でき, 結果として町をコンパクトシティにすることがで きると考えられる，これらを踏まえ本稿では，上記の藤井ら の仮説が実際に機能しているとした際に, 都市の形がどのよ うに変化するのかを, マルチエージェントシミュレーション を通して検証する。

2.2 都市と交通のマルチェージェントシミュレーション マルチエージェントシミュレーション(注2)をはじめとした 計算機実験を通して都市や交通の動態について研究がなされ てきている.マルチエージェントシミュレーションは系に存 在する個々の主体をエージェントとして表現し，これらす心゙ ての動きをシミュレーションすることを通して全体の挙動, および個々の挙動とその関係性を分析する手法である．松中 や中川らは都市内交通シミュレーションを用いてパッケージ 施策や LRT 導入の評価を行なっている ${ }^{15)}$. 奥嶋らは都市交 通政策のための人工社会モデルを構築し日常的な交通行動変 化を分析している ${ }^{16)}$.

これらのモデル化として, 都市の政策評価のための数值計 算の枠組みは一体一体を別にみて交通移動時に各エージェン トの座標位置を考慮しながら検討する座標システムょりも， ゾーン単位で考慮するゾーンシステムで検討される場合も多 い. 戸川らはゾーンシステムの上で, 土地利用モデル，買物 行動モデルを構築し政策評価を行なっている ${ }^{17), 18)}$. 松本ら はゾーンシステムをとった上で数理計画法に基づいて最適な 都市の設計を検討している。しかし，計算量の問題が生じる ことが指摘されている ${ }^{19)}$ 。これらに対して, 菊池らは座標シ ステムを導入して生活行動シミュレーションを行なう手法を 提案している ${ }^{20)}$. 交通行動の意思決定を個々のエージェント のシンプルな意思決定問題およびその学習問題に還元できる 場合には個々のエージェントの動きを座標上でモデル化する ほうが効率的な場合もある。本稿でも座標システムによるア プローチをとる.

また, 都市計画の研究における多くの研究では, シミュレー ションを行なう際に，ある地域を想定しそのパラメー夕を模 擬し，予測を行ない評価を行なおうとしている。しかしなが ら, マルチエージェントシミュレーションの特性上，また，社 会システムが開放系であるという特性上, 数值レベルでの予 測は非常に困難である。それゆえに，構成的アプローチでは， 個別的な予測を直接的に問題にするのではなく，大胆に簡略 化したモデルを用いて，構造的なレベルの検討を行なうとい う研究の方向性が存在する ${ }^{21)}$. 特にシステムの創発的な振る 舞いを見る際にこれらのアプローチは有効となる，本稿での 研究アプローチは後者に属する.

(注 2）エージェントベースモデリング (ABM) もほぼ同義であ る14). 
本稿では, ミクロな意思決定としての住人の交通行動と居 住地選択の関係性を仮定した上で生じる, 都市構造の変化とい うマクロな現象を検討することを目的とする. 土地利用と交 通行動の相互依存の動態を検証した先行研究としては, 鈴木ら の研究がある. 鈴木らは交通行動に加え, 土地利用を内生変 数化した DCUE (Dynamic Computable Urban Economic) モデルを提案し岐阜市における政策評価を行なっている ${ }^{22)}$. これに対して, 本稿では, 仮想的な都市を対象として, 政策が 都市のトポロジカルな形状に与える影響を検討し，また，現 在, 考えられているモビリティマネジメント施策をとった際 の諸変数にかかわる隠れた因果を検討することを目的として 研究を行なう.

\section{3 都市と創発システム}

都市は多くの住人が住まい, 多くの利害関係者が生態系と して接続されながら作動しているシステムである。それらの 行動主体は当然ながらに自律して作動する。一方で, その都 市における建物や交通機関の多くは人工的に生み出された物 でありながら，日々の行動主体の行動を制約する。これはま さに，ミクロな自律的行動がマクロな状態変数により制約さ れるとする創発システムの特性であり，ミクロ・マクロルー プの顕著なる例である。しかしながら，都市のダイナミクス はこれまで自律分散システム, 創発システムの文脈では活発 には議論されてこなかった。

たとえば，交通行動をとっても，一般的に人間は住居から 勤務地までの最短ルートをとるように学習するが, その経路 学習は住人の居住地, 勤務先, 道路形状, 公共交通機関の整 備状況などを制約条件としてなされる。しかし，長期で見る と, 居住地や勤務先は移転する可能性があり, また, 公共交 通や道路は整備されたり改廃される可能性がある。そしてま た，この移転や改廃は住人の交通行動にも依存するという事 態があるのである。これは都市と交通行動とのミクロ・マク ロループとして捉えることができる.

都市を創発システムとして捉えることは，都市が直接制御・ 直接設計可能であるという考えを事実上捨てることを意味し ている。これはコンパクトシティの設計論を考える上でも非 常に重要である，民主的な近代国家においては，既存の都市 を行政の力により強制的に誰かが望む姿に変容させることや, また，望む都市を新たに生み出すことは現実的には不可能で ある(注 3$)$ 。つまり，われわれは直接的に都市を所望な状態へ と制御することはできず, 諸々の施策を通じて民間の行動選 択，投資行動にバイアスをかけてコンパクトシティへと間接 制御をかけるよりほかない(注 4)。しかしながら，都市の中の

（注 3）権力者が絶対的な権力をもった古代王国などでは都市一 つを生み出すことも可能ではあったが, 各個人の所有権が保証さ れた民主主義国家では難しい。

（注 4）さらに踏み込むと行政の施策の意思決定すらさまざまな 利害関係の中で制約されており, 系の外部からの制度設計自体が 不可能であると捉える視点も重要でありうる ${ }^{23)}$ ．本稿ではこの 立場はとらず，あくまで間接制御自体は可能であるという立場を とる.
事象は相互に関係付いており，どのような施策がどのような 動的な変化を都市に与えるかについては不明確である。 そこ で,マルチエージェントシミュレーションにより,これらの変 化を検討することが考えられる。つまり，コンパクトシティ の設計論は理想状態を措定し，それを直接設計する「つくる 設計論」から，徐々にその状態に近づくように環境条件を整 える「育てる設計論」をとる必要があるのである.

$$
\text { 3. シミュレーションモデル }
$$

本稿では，前章で述べたように簡略化された都市モデルを 用いて, 環境条件に応じた住人の交通行動選択と居住地選択 から組織化される, 都市の形状変化を追う。各エージェント は日々, 通勤もしくは通学, 購買のための移動などを想定した トリップを行ない，そのときに用いる交通手段を自らの評価 関数に従って学習する。これらにより習慣が固まったところ で，各エージェントが順に転居を行なうという流れでシミュ レーションを行なう。以下に, シミュレーションの設定につ いて示す.

\section{1 都市モデル}

本稿では交通行動変化と居住地選択行動変化を同時に議論 するために，単純な都市モデルを導入する．Fig. 1 に都市モ デルの概観を示す．交通行動選択において，各エージェント は総移動コスト (total travel cost) に基づいて交通行動を決 定する。総移動コストは時間コスト, 料金コスト, 疲労コス トの三つのコストの重み付き和として計算される。エージェ ントは交通行動が学習を通して一通りに収束した後に，つぎ の居住地を現在の利用している交通手段を前提として選択す るという流れで, 都市構造の変化を追う，交通手段とは移動 を用いる際に用いる交通手段（徒歩，自転車，バスなど）を 指す.

シミュレーション空間上には二つの領域があり，一つが居 住空間 (home zone) で，もう一つが商業空間 (business zone) である．前者にはエージェントの日々の交通行動の起点とな る居住地 (home) があり, 後者には交通行動の終点となる目 的地 (destination) がある. 目的地は, 店舗やオフィス, 学校 など多くの種類の施設を含むものとする．各エージェントは 日々，このいずれかの目的地へと通勤や購買の目的で移動す るものとする。ただし，これら居住空間と商業空間は便宜的 に名付けるものであり，厳密な境界はなく，実際にはそれぞ れ居住地と目的地の分布により表現される.

居住空間と商業空間はそれぞれ一つずつの駅をもつ. 駅 A と駅 B がそれぞれ居住空間と商業空間の中心に置かれる。二

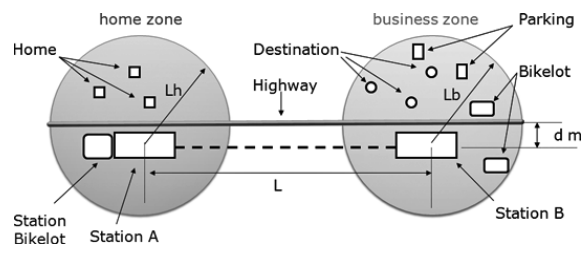

Fig. 1 Simple urban model 
次元の座標系がこの都市モデルには定義され, $i$ 番目の居住地 は $\left(x_{i}^{h}, y_{i}^{h}\right)$ の座標をもち, $j$ 番目の目的地は $\left(x_{j}^{d}, y_{j}^{d}\right)$ の座 標をもつものとする．原点は二つの駅の中点にとる。云駅間 の距離は $L$ とし駅 A と駅 B がそれぞれ $(-L / 2,0),(L / 2,0)$ に置かれる。

居住地の初期值は駅 A を中心としたガウス分布に基づいて ランダムに配置される.また, 目的地は駅 B を中心としたガ ウス分布に基づいてランダムに配置される．それぞれの分布 はそれぞれ $L_{h}$ と $L_{b}$ の標準偏差をもつ.

すべての地点は連続的に接続され，エージェントは歩行， 自転車での移動拈よび車での移動によりこの連続な空間を移 動できるものとする (注 5).これは, すべての空間において均 一な密度で道路が配置されているという大胆な過程である. 本稿では交通行動と居住地選択行動の変化に伴なう都市の動 態を可能な限りシンプルな系で観察するためにこのような仮 定を採用する。また，幹線道路が二駅間を結ぶ線路の $d \mathrm{~m}$ 北 を走る。エージェントは幹線道路では他の空間よりも高速に 移動することができる，また，エージェントは他の移動手段 により幹線道路を移動することはできない。また, 幹線道路 は特定の入り口をもたず，エージェントは $y$ 座標が幹線道路 のそれに到達した時点で幹線道路に乗り入れることが可能に なる。

また, 駅 A と商業空間内には駐輪場が置かれ, 商業空間に は駐車場も置かれる。商業空間内の各駐輪場, 駐車場は駅 B を中心としたガウス分布に従って配置される. また, 駐車場 は民間企業により運営されていると考え, 交通行動学習の終 了後に利用率が非常に小さい駐車場は除去される。

\section{2 交通行動}

各エージェントは毎日, 居住地から目的地へ向かう. 各エー ジェントの日々の交通行動は, それぞれのトリップの交通行動 の価值に従った $\epsilon$-greedy 法により確率的に決定される. 日々 の交通行動の総移動コストは時間コスト, 料金コスト, 疲労 コストの三つの重み付き和により計算される。この重みを本 稿では選好バイアスと呼ぶ.

\section{2 .1 トリップ}

交通行動分析の分野では人の移動はトリップという単位で 認識される. 出発点から目的地への一連の交通行動は交通行 動分析の分野では目的トリップ (もしくは, linked trip) と呼 ばれる。その人が複数の交通手段を用いて目的地にたどり着 いた場合でも，それら一連の交通行動をリンクトリップと呼 ぶ.一方で, リンクトリップの要素となる，一単位のトリッ プを手段トリップ (もしくは, unlinked trip) と呼ぶ. Fig. 2 に示すように，たとえば，家から会社までの移動は目的トリッ プであり, 家から駅 A, 駅 A から駅 B, 駅 B から会社への 移動は手段トリップである.

われわれの都市モデルでは, Fig. 3 に示すように, 8 種類 の目的トリップを想定する.これら 8 個の選択肢は次項で定

（注 5）ただし車の移動については渋滞の効果が考慮される。

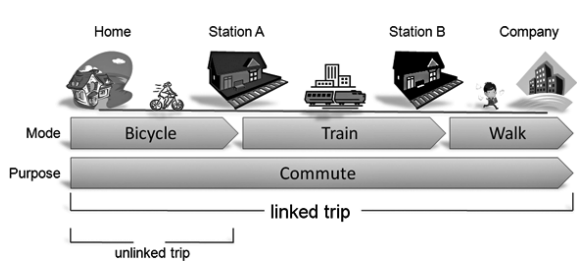

Fig. 2 Linked trip and unlinked trip

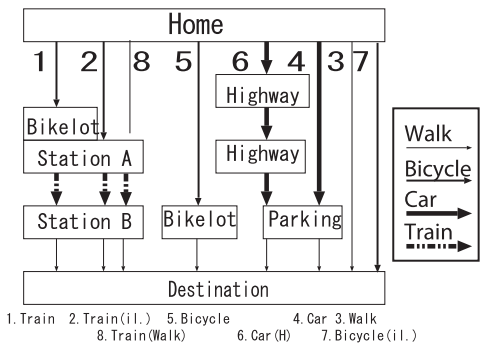

Fig. 3 Variety of trips

義される各目的トリップの価值に基づき $\epsilon$-greedy 法によって 確率的に選択される。手段トリップとして徒歩, 自転車, 自 動車, および電車が定義される. Fig. 3 内の手段トリップで 自転車で駅 A に向かっているにもかかわらず，駐輪場を経由 していないものは, 駅前に違法駐輪していることを示す．違 法駐輪を行なう自転車は確率 $P_{r}$ で撤去され，エージェント は罰金としてのコスト $c_{R}$ を支払うことになる。

Fig. 3 中の各トリップについて，1，2，8 は電車利用を 行なうが, 1 は自転車で駅までいき駐輪場に自転車を停める [Train], 2 は違法駐輪する [Train(il.)]，8は徒歩で駅へいく [Train(Walk)]. 5, 7 は自転車で直接目的地へ向かうが， 5 は 目的地そばの駐輪場に自転車を停め [Bicycle], 7 は目的地そば に違法駐輪する [Bicycle(il.)]. 4, 6 は自動車で直接, 目的地 へ向かうが, 4 は幹線道路を用いず直接目的地へ向かい [Car], 6 は幹線道路を用いて目的地へ向かう $[\mathrm{Car}(\mathrm{H})]$. 角括弧 [] 内 は，ぞれぞれのトリップの略称を示しており，後に実験結果 の考察時に用いる。

手段トリップの中で, 最も代表的な交通手段は代表交通手 段と呼ばれる．基本的に代表交通手段となる優先度は電車， 自動車，自転車，そして徒歩の順である。

3.2.2 コスト

それぞれのエージェントは $i$ 番目の手段トリップの総移動 コスト $C_{i}$ に基づいて各目的トリップの価值 $V_{i}$ を学習する.

・総移動コスト $C_{i}$

$$
\begin{aligned}
& C_{i}=\omega_{T} C^{T}+\omega_{M} C^{M}+\omega_{F} C^{F} \\
& \omega_{T}, \omega_{F}, \omega_{M} \geq 0
\end{aligned}
$$

$C^{T}, C^{M}$, と $C^{F}$ はそれぞれ時間コスト, 料金コスト, 疲労コ ストを表わす。同様に， $\omega_{T}, \omega_{F}$ ，と $\omega_{M}$ はそれぞれ時間コス 卜，料金コスト，疲労コストの選好バイアスを表わす。それ ぞれの值はエージェントにより異なる，本稿の実験では，こ れらを一定とした。 
・時間コスト $C^{T}$

$$
C^{T}=\eta^{T} T
$$

ここで $T$ はエージェントが出発地から目的地に到達する時間 であり, $\eta^{T}$ は時間をコストに変換する係数である.

・料金コスト $C^{M}$

$$
C^{M}=c_{b}+c_{c}+c_{t}+c_{G} T_{c}+c_{R} .
$$

料金コストは駐車場代金 $c_{c}$ と, 駐輪場代金 $c_{b}$, 電車賃 $c_{t}$, ガ ソリン代 $c_{G} T_{c}$ ，および駐輪撤去のペナルティ $c_{R}$ の和として 表現される．ガソリン代金は運転時間 $T_{c}$ に比例する．もし， エージェントが違法駐輪を行なった場合には, 確率 $P_{r}$ で撤 去される.

・疲労コスト $C^{F}$

$$
C^{F}=\left(F_{w} T_{w}+F_{b} T_{b}+F_{c} T_{c}+F_{t} T_{t}\right)+F_{c o n}
$$

$T_{w}, T_{b}, W_{c}, T_{t}$ はそれぞれ歩行, 自転車, 自動車, 電車による 移動時間を表わす。 $F_{w}, F_{b}, F_{c}, F_{t}$ は時間からコストへ変換す る係数である。これに渋滞による疲労コストを表わす $F_{c o m}$ を足すことで疲労コストが計算される。

総移動コスト $C_{i}$ は毎日エージェントが目的地に着くたびに 計算される (注 6). 総移動コストを受け取った後に，エージェ ントは $i$ 番目の目的トリップの価值を下のように変化させる.

$$
V_{i} \longleftarrow \alpha\left(-C_{i}\right)+(1-\alpha) V_{i}
$$

日々の交通行動はこの価值に基づいた $\epsilon$-greedy 法により毎日 決定される. $\epsilon$-greedy 法では, 最も価值のあるルートが $1-\epsilon$ の確率で選ばれ, 別のルートがランダムに確率 $\epsilon$ で選ばれる. $\epsilon$ は下式に従って $(\gamma<1)$ 徐々に減衰させる.

$$
\epsilon \longleftarrow \gamma \epsilon
$$

$\epsilon$ は試行を重ねるたびに徐々に 0 に向かう.

\section{2 .3 渋滞の影響}

エージェントが渋滞の中を移動した際には, 追加での時間 コストと疲労コストを考慮する。本稿のモデルではエージェ ント周辺のエージェントの密度が $D_{0}\left[\right.$ agents $\left./ \mathrm{km}^{2}\right]$ より大き くなった際に渋滞が発生すると考える.

渋滞下における車の移動速度 $V_{c}$ は以下のようにして決定 する。

$$
V_{c}=\max \left(V_{c}^{\min }, \min \left(\eta_{v} \times\left(D-D_{0}\right)+\alpha_{v}, V_{*}\right)\right)
$$

$D$ はエージェント周り $100 \mathrm{~m}$ 四方でのエージェントの密度を 表わし， $\eta_{v}$ は変換係数を表わす． $\alpha_{v}$ は定数項を表わす． $V_{*}$ は車の通常速度を表わし，これは道の種類に依存する。つま り, 幹線道路では $V_{*}=V_{h}$ となり, 通常の道路では $V_{*}=V_{c}$ となる，これらの式は参考文献 24) を参考に作成した. 渋滞による疲労コストは下記のように算出される.

（注 6）駐輪撤去や渋滞といった不確定な事象により, 同じルー トであっても総コストは毎回変化する.

$$
F_{c o n}=\min \left(F_{c o n}^{\max }, \eta_{c o n} D\right)
$$

ここで $F_{\text {con }}$ は渋滞による疲労コストを表わし， $\eta_{\text {con }}$ は密度 から疲れへの変換係数を表わす。また， $F_{\text {con }}$ は $F_{\text {con }}^{\max }$ を超 えないものとする。

\section{2.4 移動}

本稿の実験では，すべてのエージェントは居住地を同時に 出発する。エージェントは現在の位置から, 現在選択してい る手段トリップのゴールに向かって直進するものとする。ま た，自転車や自動車で移動するエージェントは合法的に最終 目的地に最も近い，駐輪場もしくは駐車場に停めなければな らない.

\section{3 居住地選択行動}

本節では，居住地選択行動のアルゴリズムについて記述す る.十分な日数が経過し交通行動が収束した後に，エージェ ントの一部は自らの居住地を変更する.

まず，居住地を変更することになったエージェントには， いくつかの候補がランダムに提示される。この候補は現在の 居住地の分布をガウス分布でモデル化した後に，このガウス 分布から生成されるものとする。エージェントはいくつかの 候補が提案された後に，この候補の中から，最も自らの総生 活コスト $C_{i}^{l}$ が最小となる居住地を選ぶことで転居先を決定 する。具体的には，一度，提案された候補地に仮想的に転居 した後に，学習された交通手段を用いて目的地へ移動するこ とで候補地における総移動コスト $C_{i}$ を見積もる. 総生活コ スト $C_{i}^{l}$ は地代 $r_{i}$ と総移動コスト $C_{i}$ の和で表わされるもの とする.

ここで藤井らの研究 ${ }^{4)}$ に基づき，居住地選択を行なうとき の総生活コスト計算には転居前の交通行動選択を用いること にする．

$$
C_{i}^{l}=r_{i}+C_{i}
$$

それぞれの地域での地代 $r_{i}$ は下記に従うものとする.

$$
r_{j}=\eta_{r} I_{j}\left(\frac{H_{j}}{A_{j}}\right)
$$

居住空間，商業空間には一定区画ごとに地代を設定する．本 研究においては 1 区画を $100 \mathrm{~m} \times 100 \mathrm{~m}$ とする．地代は戸 川の研究で用いられた土地消費量と地代の関係を示すデー夕 を参考にしている ${ }^{18)}$. $A_{j}$ は一区画の広さを表わし， $H_{j}$ は その区画で住人や会社が消費する面積を示す。これは，人口 の集中が地代を上昇させることを意味する。

転居前に候補地の総生活コスト $C_{i}^{l}$ を計算するために各エー ジェントは仮想的に目的地への移動を行なう。この際に，他 のエージェントも同時に移動を行なうことで渋滞などの影響 も加味した上で，それぞれのエージェントは総生活コストを 見積もることができる。このようにして，エージェントの居 住地選択行動はエージェントの習慣的な交通選択行動に影響 を受けることとなる。 


\section{4. 実 験 1}

\section{1 実験条件}

実験で用いたパラメータを Table 1 に示す(注 7)。実験で は, 交通行動選択では 30 日間の学習を行ない, その後に居住 地選択を行なうというループを 10 回行なった。この際，一 度に転居するエージェントは全体の $1 / 10$ とした。

本実験ではモビリティマネジメントにおけるコミュニケー ション施策を極端にした形である $(\mathrm{MM} X \%)$ 条件と, ガソ リン価格を上昇させる (gas price $\times Y)$ の二つの施策によっ て, 自動車からその他の交通へのモードシフトと, その波及 としての居住地選択行動への影響による居住地の分布变化を 検証する.

モビリティマネジメント施策の一つとして TFP (Travel Feedback Program) と呼ばれる施策がある.これは, 居住 者一人一人にコミュニケーションを通して, 自動車から公共 交通への乗り換えをさまざまな情報提供を通して実現してい くアプローチである ${ }^{8)}$ 。これは，コストへのアプローチでは なく，社会的な態度へのアプローチであるといわれる ${ }^{25)}$. 目 に見えるコストの変化ではなく, 意思決定における態度にア プローチして交通行動を変化させようというものである。こ のシミュレーション上の表現として, $(\mathrm{MM} X \%)$ 条件では, $X \%$ の自動車利用者が電車利用に乗り換えるように変化させ られるとする，もう一つの条件である (gas price $\times Y$ ) 条件 ではガソリン価格が $Y$ 倍になるとする。この価格上昇は原油 の枯渇による石油価格の高騰が原因であるとしても, 政策的 に炭素税などの措置により高騰したと捉えても構わない。こ れら前提の下で, (MM 0\%, 20\%, 50\%, 100\%), および (gas price $\times 2, \times 5, \times 10, \times 100)$ の条件の下で実験を行なった.

\section{2 実験結果}

Fig. 4 は居住地区, 商業地区のそれぞれの初期分布をしめ している. 黒い正方形が二つの駅を表わしている. また，そ れぞれの実験条件下で 3 回の実験を行ない, その平均の結果 を下に示す。学習初期において各交通手段の価值は 0 で初期

（注 7）すべてのパラメータはさまざまな資料からの断片的な情報 に基づき, 比較的自然と考えられる值を設定した。徒歩速度, 自転 車速度は一般的に平均速度 $4 \mathrm{~km} / \mathrm{h}(66 \mathrm{~m} /$ 分 $), 16 \mathrm{~km} / \mathrm{h}(267 \mathrm{~m} /$ 分) といわれている。 また幹線道路での車速度については, 国土 交通省の統計から一般国道での平均速度が $36 \mathrm{~km} / \mathrm{h}(600 \mathrm{~m} /$ 分) であることを参考とした。ガソリン代については国土交通省統 計より実走行燃費 $9.7 \mathrm{~km} / \mathrm{L}$ ，本実験を行なった際の平均ガソリ ン価格が 122 円/L であることから算出した。電車代は JR の普 通運顀を元に求めた，疲労コストの係数については, 周囲の人間 に対する聞き取り調査を行ない決定した。具体的にはそれぞれ 手段トリップの条件について時間数を変化させながら「どちら が疲れるか? 」「電車の運賃がいくら以下なら歩かず電車にのる か? 」のような質問を行なうことで適切と考えられる值を探索し た。違法駐輪罰金は一例として京都市における撤去時の撤去・保 管の費用 2300 円に返還場所まで取得しにいく際のコストを多少 加味したものとした，しかし，これらは十分に正確な值とはいい 切れず，この值の変化により当然結果は変化するが, 本稿ではこ れらの微少な違いに依存しない範囲で議論を進めるよう配慮し議 論を進める。
Table 1 Paremeters

\begin{tabular}{|l|c|}
\hline Parameter & initial value (unit) \\
\hline \hline Number of agents & 1000 \\
\hline Number of homes & 1000 \\
\hline Number of destinations & 1000 \\
\hline$\epsilon$ & 0.7 \\
\hline$\alpha$ & 0.5 \\
\hline$\gamma$ & 0.94 \\
\hline Walk speed $V_{w}$ & $66(\mathrm{~m} / \mathrm{min})$. \\
\hline Bicycle speed $V_{b}$ & $267(\mathrm{~m} / \mathrm{min})$. \\
\hline Car speed $V_{c}$ & $450(\mathrm{~m} / \mathrm{min})$. \\
\hline Train speed $V_{t}$ & $\mathrm{~L} / 7+350(\mathrm{~m} / \mathrm{min})$. \\
\hline Bicycle speed $V_{c h}$ & $600(\mathrm{~m} / \mathrm{min})$. \\
\hline Walk fatigue cost $T_{w}$ & 220 \\
\hline Bicycle fatigue cost $T_{b}$ & 80 \\
\hline Car fatigue cost $T_{c}$ & 20 \\
\hline Train fatigue cost $T_{t}$ & 40 \\
\hline gas price $c_{G}$ & $0.01(\mathrm{yen} / \mathrm{m})$ \\
\hline
\end{tabular}

\begin{tabular}{|l|c|}
\hline Parameter & initial value (unit) \\
\hline \hline Train fare $c_{t}$ & L×0.04(yen $/ \mathrm{m})$ \\
\hline$\eta^{T}$ & $30($ yen $/ \mathrm{min})$. \\
\hline Number of bicycle parkings & 1000 \\
\hline Number of car parkings & 1000 \\
\hline Bicycle parking fare $c_{b}$ & $150(\mathrm{yen})$ \\
\hline Car parking fare $c_{c}$ & $800(\mathrm{yen})$ \\
\hline Distance between two stations $L$ & $4000(\mathrm{~m})$ \\
\hline Distance between the highway & $10(\mathrm{~m})$ \\
and the rail track $d$ & $3200(\mathrm{~m})$ \\
\hline home zone size $L_{h}$ & $3200(\mathrm{~m})$ \\
\hline business zone size $L_{b}$ & 0.5 \\
\hline Ratio of removal of illigal bicycle $P_{r}$ & $3000(\mathrm{yen})$ \\
\hline Illegal bicycle penalty $c_{R}$ & 4 \\
\hline Car parking capacity & $140\left(\mathrm{~m}^{2}\right)$ \\
\hline Size of a home & 1000 \\
\hline Rent coefficient $\eta^{r}$ & $100\left(\mathrm{~m}^{2}\right)$ \\
\hline Zone size & \\
\hline
\end{tabular}

化されるために交通行動の分布は確率的に一様となる。

各試行において，エージェントは開始後，それぞれの条件 下で学習をすすめ 30 日間の学習で交通行動を固定化させて いった。この際の学習過程の一例を Fig. 5 に示す。横軸は 日数を示し．縦軸は各リンクトリップの分担割合を示す，

また，交通行動の変化のみならず，転居を繰り返すことに よって，エージェントは自らの支払うコストを減少させてい く. Fig. 6 に実験結果の一例として, 各転居のステップごと のエージェントの地代 (Rent) と総移動コスト (Travel Cost) と総生活コスト (Total Cost) の全エージェント和の変化を表 示する．全体としての総生活コストが減少するように系が変 化していっていることがわかる.

Fig. 7 は何の政策もとられなかった際の最終的な居住地の 分布とそれぞれの交通手段の利用率を示す．居住地の分布は 商業地区の周辺にひろがり，多くの人は車を用いて，目的に に向かい，少しの人だけが他の交通手段を用いた。

Fig. 8 はすべての自動車利用者が電車を使うように転換さ 


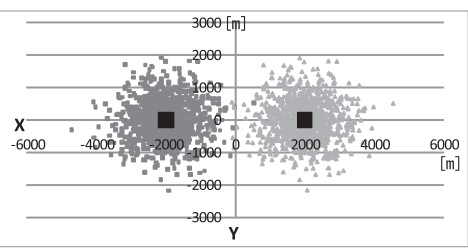

Fig. 4 Initial positions of homes and destinations

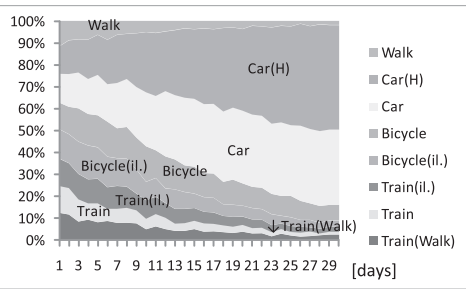

Fig. 5 Transition of utilization ratio of each travel mode

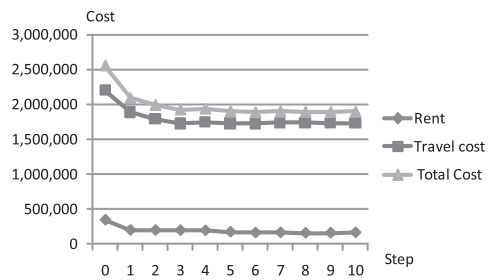

Fig. 6 Transition of each cost for each iteration of residential choice behavior

れた際の，最終的な居住地の分布と交通手段の利用率を表わ している．交通行動の変化に伴い，それが有利に働くような 居住地へ向かうために，居住地の分布がコンパクトになって いる.

Fig. 9 はガソリン価格が 100 倍に跳ね上がった場合の結果 を表わしている。この条件下でも, やはり都市の構造はコン パクトになっているが $(\mathrm{MM} \mathrm{100 \% )}$ 条件と比較すると，質的 な差がある。この条件下では, コンパクトにはなっているが, 居住地区の分布は (MM 100\%) 条件に比べると, 多少広く分 布している。また，居住地区と商業地区の間にクラスターが 生まれており，分析した結果，ここに住む人は自転車を用い て，目的地へと直接向かっていることがわかった。

$\mathrm{CO}_{2}$ の排出量，交通に求められる都市空間，各エージェン トの総生活コストの総和を簡便な手法で計算した．文献 26) に報告される UPI report (Umwelt-und Prognose-Institut report) がそれぞれの交通手段における環境負荷の相対的な 值を Table 2 のように報告しており，単純にこれらの值を， 交通手段利用の割合に掛け合わせ比較することにより，相対 的な環境負荷の変化を調べた。

Fig. 10 は $\mathrm{CO}_{2}$ 排出量を, Fig. 11 は必要空間を，また， Fig. 12 はすべてのエージェントの総生活コストの総和を表 わしている。これらの縦軸は UPI report の各交通手段の負 荷の比率に基づくものであり，相対的な指標のみに意味があ り，絶対的な值は意味をもたない.

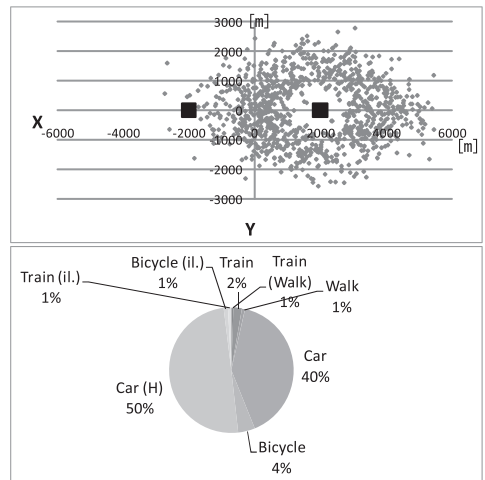

Fig. 7 Final distribution of residences without political measures (top) and utilization ratio of each mode without political measures (bottom)

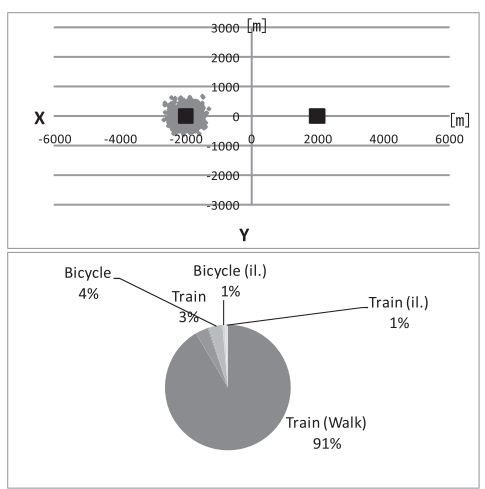

Fig. 8 Final distribution of residences with $100 \%$ mobility management (top) and utilization ratio of each mode with $100 \%$ mobility management (bottom)

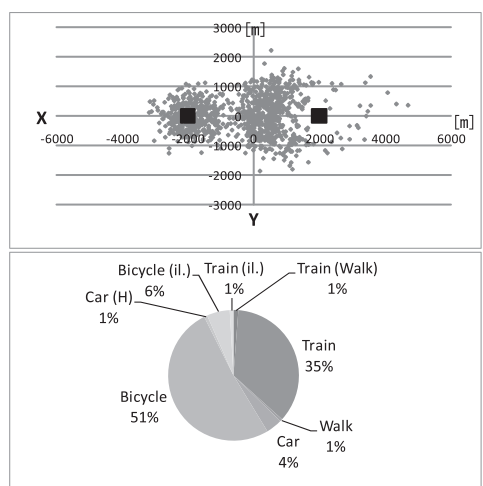

Fig. 9 Final distribution of residences with 100 times gas price (top) and utilization ratio of each mode with 100 times gas price (bottom)

Table 2 Comparison of environmental impact of transport modes (base $=100$ for private car)

\begin{tabular}{|c|c|c|c|c|}
\hline & Car & Train & Walk & Bicycle \\
\hline $\mathrm{CO}_{2}$ & 100 & 30 & 0 & 0 \\
\hline Space consumption & 100 & 6 & 4 & 2 \\
\hline
\end{tabular}

\section{3 議論と考察}

強制的な公共交通への乗り換えは $\mathrm{CO}_{2}$ の排出を十分に減ら すことはなかった，MM 100\%の条件では，最終的には $\mathrm{CO}_{2}$ 


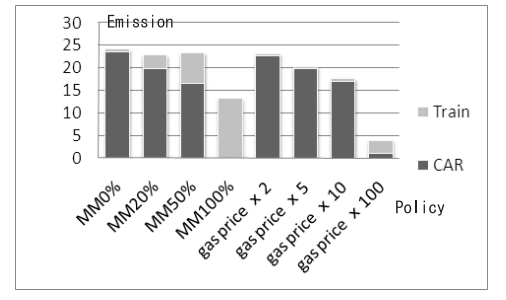

Fig. $10 \mathrm{CO}_{2}$ emission for each condition

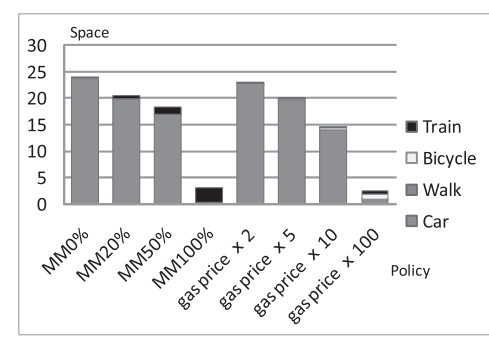

Fig. 11 Required urban space for transprtation for each condition

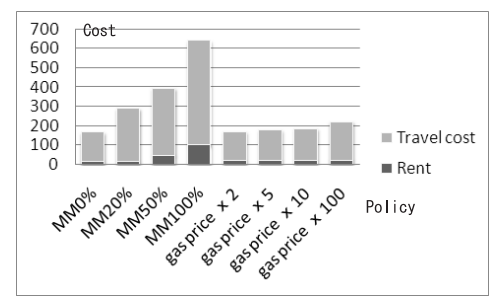

Fig. 12 Total cost of all agents for each condition

の排出量は半分程度に収まった。しかし, 電車へのモードシ フトは全体としての総生活コストを急激に上昇させた。これ はまた, 駅 A 周辺の地価上昇や駅まで歩くことについての疲 労コストや時間コストの上昇に起因するものと考えられる. 確かに, 居住地の分布はコンパクトになっている.しかし， このような政策は，住民の負担を増大させるのみならず，都 市空間の効率的利用や, $\mathrm{CO}_{2}$ 排出削減の視点からみても, そ れほど大きな効果はもたないことがわかる(注 8$).$

これに対し，ガソリン価格を上昇させると $\mathrm{CO}_{2}$ の排出と 必要空間はなだらかに減少した. MM 100\%条件に比べると 居住空間の分布は広がっているにもかかわらず， $\mathrm{CO}_{2}$ 排出や 必要空間は減少した。このことは, 直感的なコンパクトさが, 必ずしも本質的なコンパクトさに結びつかないことを示唆し ている，さらに，ガソリン価格の上昇にもかかわらず，総生 活コストはそれほど増加しなかった。これは，エージェント が交通行動と居住地を柔軟に変化させることで自らの出費を 減らした結果である. gas price $\times 100($ Fig. 9) 条件での特徵 的な結果は，自転車と電車がそれぞれにトリップを分担して いた点にある。電車は確かに優れた交通機関であるが，一方 で，やはり電力消費による $\mathrm{CO}_{2}$ 排出もある，また，徒歩と 電車の組み合わせでは駅の周辺に過度な集中が生まれる。一

（注 8）ただし，これらの結果は UPI report の係数を単純にか けるという評価手法による影響もある。
方で，自転車は本質的に $\mathrm{CO}_{2}$ を排出せず，都市空間の消費 も小さい．自転車を上手く利用した施策の実現が重要になる であろう。

\section{5. 実 験 2}

つぎに自転車撤去の影響について考察を行なうために実験 を行なった。駅前や道路上の駐輪自転車に対して，徹底した 撤去を行なった場合，自転車の利便性が低下し，結果として 自動車へのモードシフトを生む可能性がある。

\section{1 コンパクトな都市と自転車}

コンパクトな都市を実現するにあたって公共交通の充実と， 歩行空間の整備は必要である。国内では，たとえば京都市は 「歩くまち・京都」憲章を制定し歩行者を中心としたまちづく りを進める意思表示を行なっている，その一方で, 自転車も コンパクトな都市に適合した移動手段である。藤井は脱クル マ社会においては公共交通を補完する意味で，自転車が必要 となることを端的に指摘している ${ }^{27)}$ 。また，自転車利用は交 通のみへの効果に制限されず，健康や環境など多方面におい て優れた移動手段であることが指摘され，各国で促進策がと られている28).

しかしながら，自動車社会である現在の状況から見ると自 転車は扱いづらい存在であり，歩道走行における歩行者への 危険性，駅前などでの違法駐輪など否定的な面ばかりが強調 されやすい。また自動車産業，公共交通と異なり利益団体も 少ないことから振興策への後押しが弱い。これらから，地方 自治体の中には，まちの景観や安全，住環境の維持から違法駐 輪に対しては積極的な撤去を行ない，抑止することが住「環 境」の向上のために重要であると考えて，自転車に利するより も，厳しくあたる自治体も多い。藤井らはコミュニケーショ ン施策を通して違法駐輪を減らすというモビリティ・マネジ メントの研究を行なっている ${ }^{29), 30)}$. しかし，このような違 法駐輪の抑止は，自転車利用抑止に繋がり，場合によっては 自動車へのモードシフトを生むのではないかという懸念は, まったく議論されてこなかった，本稿では，マルチエージェ ントシミュレーションを用いることで，このような隠れた因 果関係を検討することを目指す.

\section{2 実験条件}

実験条件は実験 1 と同じ值を用いた。自転車撤去率 $P_{r}$ の みを変化させ，その場合における各交通手段の負担割合を観 察した． $P_{r}$ を $0 \%, 1 \%, 3 \%, 5 \%, 10 \%, 50 \%$ と変化させて実 験を行なった。

\section{3 実験結果}

結果を Fig. 13 に示す。 $P_{r}=0$ ，つまり，撤去を行なわ ない状態では，すべての住人は自由に自転車で走行し，ドア トゥードアであらゆる場所にアクセスすることができる．この 利便性から多くのエージェントは自転車で直接通勤を行ない, 目的地の目の前までいく Bicycle(il.) を採った. $P_{r}$ を $50 \%$ ま で増大させると, 徐々に違法駐輪を行なうエージェントは減 少し, Bicycle(il.) および駅前に違法駐輪をする Train(il.) は 


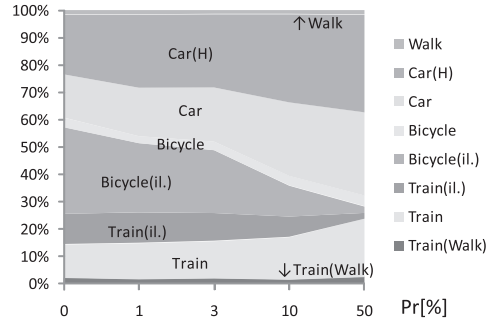

Fig. 13 Changes in trip selection delending on removal probability

約 90\%減少した. Fig. 13 では代表交通手段順に分担率を示 している。この図から違法駐輪をするエージェントは減少し たが，その変化先には大きく二通りあることがわかる．まず， 電車利用者の割合が $25 \%$ 程度で変化していないことが観察さ れる。これより, 駅前に違法駐輪していたエージェントの多 くは, 駐輪場利用に切り替えたものと考えられる。これは, 駐輪場がコスト 150 で利用可能なため, 撤去による損失を考 えた場合, 期待值としては駐輪場を選択したほうが有利になっ てくるためである．別のいい方をするとエージェントが合理 的意思決定をするならば, 駅前駐輪のコストは $P_{r}$ に比例し て増加するが 150 を上限として増加しなくなるために, 電車 利用のコスト増は高どまる。ただし，ここで駅前駐輪場の容 量の上限を設けていないことは注意すべきである。もし，こ れに上限があった場合には, 自動車利用など別の交通手段へ さらにシフトすることが考えられる.

一方で直接目的地へ向かう交通行動 $(\mathrm{Car}(\mathrm{H}), \mathrm{Car}$, Bicycle(il.), Bicycle, Walk) では, Bicycleの減少分が, そのまま Car と $\operatorname{Car}(\mathrm{H})$ の増加につながっていることが見て取れる. これは多くの目的地において, 街の中に点在する駐輪場から 目的地への距離があるために Bicycle(il.) から Bicycleへの シフトはコスト高になり, Bicycle(il.) で目的地まで乗り付け られる利便性を活用することができなくなったために, 自動 車への乗り換えが進んだものと考えられる．自転車は自動車 に比べて店舗や事務所の目の前まで乗り付けられることが, 重要な機能として多くの利用者に認識されている. 本研究で も, まさに, この機能の欠損により自動車利用へのシフトが 起きた.

違法駐輪の撤去を行なうことでの住人の交通行動の変化は, 違法駐輪の代替としての駐輪場の配置と密接にかかわってい る. 通常, 直接目的地に向かう場合の自転車利用の駐輪場は 分散型になる一方で, 電車利用の場合の駐輪場は集中型とな り, その運営のコストも変わる。交通法規上は違法駐輪は犯 罪であり抑止されるべきであるが，駐輪場を十分量配置でき ず，またそれらに対する適正な価格設定と運用ができない現 実の系においては，違法駐輪により自転車のトリップ分担率 が担保されている可能性がある。コンパクトシティにむけた モビリティマネジメントに拈いて自転車の活用は重要である. 違法駐輪排除の徹底は自転車という手段トリップのコストを 増大させ, 都市の動態としては結果的にコンパクトシティへ
のベクトルと逆のベクトルを与えかねない危険性がある. 脱 クルマ社会を経て，コンパクトシティ形成のためには，秩序 をもった自転車利用の増大，つまり，駐輪場の徹底的な整備 とその料金の低価格維持か, もしくは路上駐輪への寛容な取 り扱いが求められる。もし，これらなく，自転車撤去を徹底 すると，その分担が結局は自動車に逃げることになり，歩行 者中心のまちづくりとは逆の結果を得てしまう可能性がある ことを本実験は示唆している。

\section{6. 結言}

本稿では, 個人の交通行動選択と居住地選択を含んだシン プルな都市モデルを提案し，実験を行なった。この都市モデ ル上で自動車利用を減らすための複数の施策を検証し，その 質的違いを観察した。結果として，人間の社会的態度に訴え， 強制的に電車利用に乗り換えさせるような施策は，電車利用 者を増やし，居住地の分布を駅周辺にコンパクトにはするが, 一方で，地代の上昇や，駅までの交通コストの増大によって エージェントの総生活コストを増加させることがわかった. 一方で，ガソリン価格を上昇させることは，エージェントの 総生活コストをそれほど増大させずに, $\mathrm{CO}_{2}$ 排出を減少させ ることがわかった。これは, 社会的態度に訴求して人々の交 通行動を恣意的な方向に変化させることでコンパクトシティ を目指す手法は，ガソリン価格を上昇させた上で，何の交通 手段を用いるかは自らに選択させる手法に比べて社会的によ り高価になることを示唆している。しかし，モビリティマネ ジメントに扔ける TFP を自動車から電車への強制的な乗り 換えと解釈することは, かなり乱暴であり，より適切なモデ ル化の方向性が求められる.

また, 自転車の違法駐輪問題を本シミュレーションの枠組 みの中で議論した。撤去率を変化させることで, 自転車撤去 を行なえば行なうほど，その分担割合が自動車利用へ逃げ， 結局は脱クルマのコンパクトシティ形成とは逆方向に向かい かねないことが示唆された。

本稿では渋滞については, 自動車のみについて考慮したが, 電車に扔いても満員電車が疲労コス卜を増加させることなど も考えられるし，通学路などにおいては自転車ですら渋滞す ることが起こりうる。 また, 本実験では電車の運賃は一定で あるとしたが，実際には利用者の増減にあわせて長期的には 変化する，このように，本モデルは，多くのマルチエージェ ントシミュレーションと同様に，すべての考えうる要素を網 羅したモデルではなく，それらの影響が都市構造変化にかか わる議論に強い影響を与えるという仮説をもつ場合には，こ れらも含めた議論を行なうべきである，ただ，構成的研究に おいては，構成要素をできるだけシンプルに保つことがモデ ルの見通しを良くするために重要でもあり，今回は考慮しな いこととした。

都市における各エージェントは制約条件下で徐々に自らの コストを最小化するように，ある程度確率的に行動する。交 通行動と居住地選択行動の相互の影響は，この視点からする 
と, 二つの変数のグループを交互に最適化していくプロセス として理解できる。つまり，ある制約条件の下での社会的厚 生の最適化問題を自律分散的に解くプロセスとも見なせる. この理解の上から示唆されることは, この最適化手法は局所 解に陥るということであり, 都市を望ましい状態に至らしめ るために採られるべき施策も都市の状態, つまり, 初期值に 依存して変わるということである，今後は，施策の初期值依 存性の見地に立った上での都市のダイナミクスの理解も進め たい。また，マルチエージェントシミュレーションの文脈に おいては，提案したシンプルな都市モデルのフレームワーク 上で，都市システムに隠れた因果関係を抽出することが，今 後の課題である.

謝辞 本研究を行なうに当たり，「不便の効用を活用したシ ステム論の展開」(平成 21 年度 25 年度, 科学研究費補助金 基盤研究 (B)）および「記号過程を内包した動的適応システ ムの設計論」(平成 19 23 年度, 科研費学術創成, 19GS0208 の一部支援を受けた。

\section{参 考 文 献}

1）北村隆一：ポスト・モータリゼーション一 21 世紀の都市と交 通戦略, 学芸出版社 (2001)

2）三浦 展：ファスト風土化する日本一郊外化とその病理, 洋泉 社 (2004)

3）海道清信：コンパクトシティ一持続可能な社会の都市像を求 めて, 学芸出版社 (2001)

4）藤井 聡：交通行動が居住地選択に及ぼす影響についての仮説 検証：コンパクト・シティへの誘導に向けた交通政策に関する 基礎的研究, 交通工学, 43-6, 53/62 (2008)

5）丸田 一：「場所」論—ウェブのリアリズム, 地域のロマンチ シズム, エヌティティ出版 (2008)

6）鈴木 勉：コンパクトシティ再考一理論的検証から都市像の 探求へ, 学芸出版社 (2008)

7）ジェーン・ジェコブス：アメリカ大都市の死と生, 鹿島出版会 (1977)

8）藤井, 谷口：モビリティ・マネジメント入門一「人と社会」を 中心に据えた新しい交通戦略，学芸出版社 (2008)

9）望月，中川，笠原：わが国の公共交通政策における富山ライト レールプロジェクトの意義に関する研究, 日本都市計画学会都 市計画論文集，42-1，63/68 (2007)

10）土居，榎田，近藤：LRT が京都を救う一都大路まちづくり大 作戦，京都の交通今日と明日，つむぎ出版 $(2004)$

11）谷口，高野，原：かしこい車の使い方を目指したトラベル． フィードバック・プログラムの試み，オペレーションズ・リ サーチ，48-11, 814/820 (2003)

12）谷口 守：コンパクトシティとモビリティ・マネジメント，国 際交通安全学会誌，31-4, 44/51 (2006)

13）藤井, 染谷: 交通行動と居住地選択行動の相互依存関係に関す 万行動的分析, 土木計画学研究·論文集, 24-3, 481/488 (2007)

14）出口 弘：エージェントベースモデリングによる問題解決エージェントベース社会システム科学, OR 学会誌, 49-3, $161 / 167(2004)$

15）松中, 谷口, 若林：都市構造の変化を考慮した LRT 整備の環 境影響評価一都市内交通シミュレーションモデルを用いて—, 日本都市計画学会都市計画論文集，42-3, 961/966 (2007)

16）奥嶋，秋山：局所的相互作用を考慮した都市交通政策評価の ための人工社会モデル，土木学会論文集 D, 63-2，134/144 (2007)

17）戸川，加藤，林：買物行動モデルを用いた大型店郊外立地規制 の影響評価, 日本不動産学会学術講演会梗概集, 24, 181/188
(2008)

18）戸川，林，加藤：マルチエージェントアプローチによる均衡型 土地利用モデルの拡張, 第 37 回土木計画学研究発表会投稿原 稿, CD-ROM (2008)

19）松本，玉置，稲元：都市と交通の数理計画モデル，第 21 回自 律分散システムシンポジウム，273/278 (2009)

20）菊池，藤井，北村：座標システムを導入した生活行動シミュ レーションモデルによる交通政策評価，2001 年度第 36 回日 本都市計画学会学術論文集, 577/582 (2001)

21) J.M. Epstein and R.L. Axtell: Growing Artificial Societies: Social Science from the Bottom Up (Complex Adaptive Systems), The MIT Press (1996)

22）鈴木，武藤，小川：都市の郊外化抑止と中心市街地活性化の ための土地開発規制策評価，土木計画学研究・論文集，19-2, $195 / 202(2002)$

23）谷口，山田，大島：ソフトシステムズ方法論に基づいた市民参 加の為の場の構築一自転車都市・京都への対話空間の取り組 み, 第 37 回 知能システムシンポジウム, 287/292 (2010)

24) 西成活裕：渋滞学，新潮社 (2006)

25）北村，佐々木，山本，森川，藤井：交通行動の分析とモデリン グ—理論/モデル/調査/応用，技報堂出版 (2002)

26) Implementing Sustainable Urban Travel Policies: Moving Ahead: National Policies to Promote Cycling, Organization for Economic (2004)

27）藤井 聡：自転車を巡る都市交通計画論，交通工学，40-5, $5 / 9$ (2005)

28）古倉宗治：自転車利用促進のためのソフト施策一欧米先進諸 国に学ぶ環境・健康の街づくり，ぎょうせい (2006)

29）藤井, 小畑，北村：自転車放置者への説得的コミュニケーショ ン：社会的ジレンマ解消のための心理的方略，土木計画学研 究・論文集, 19-1, 439/446 (2002)

30）萩原，藤井，池田：心理的方略による放置駐輪削減施策の実務 的検証：東京メトロ千川駅周辺に打ける事例，土木計画学研 究・講演集，34,325 (2006)

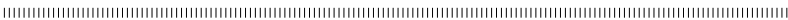

$$
\text { [著 者 紹 介] }
$$

谷口忠 大 (正会員)

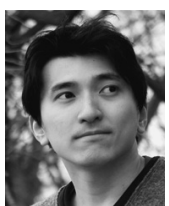

2006 年京都大学工学研究科博士課程修了. 2005 年より日本学術振興会特別研究員 (DC2), 2006 年 より同 (PD). 2007 年より京都大学情報学研究科 にて (PD) 再任. 2008 年より立命館大学情報理工 学部助教, 2010 年より同准教授。個体と組織に㧍 ける記号過程の計算論的な理解や共生社会に向け た知能情報学技術の応用研究についての研究に従 事. 京都大学博士 (工学). 計測自動制御学会学術 奨励賞，システム制御情報学会学会賞奨励賞，論 文賞，砂原賞など受賞．計測自動制御学会，日本 人工知能学会，システム制御情報学会，日本神経 回路学会などの会員.

\section{高 橋 佑 輔}

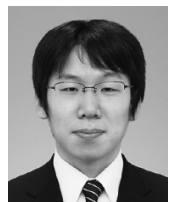

2010 年立命館大学情報理工学部知能情報学科 卒業. 2010 年より北陸先端科学技術大学院大学知 識科学研究科博士前期課程. 主たる興味：マルチ エージェントシミュレーション, 地域活性化，コ ンパクトシティ，地域通貨。 